\title{
Inquiry-Based Learning to Increase Students' Creative Thinking Skills in Vocational High School
}

\author{
Luthfiyah Nurlaela $^{1}$, Suparji ${ }^{2}$, Karno Setyo Budi ${ }^{3}$, Sheila Ayu Pratama ${ }^{4}$, Yuyun Irawati ${ }^{5}$ \\ Home Economics Department ${ }^{1}$ \\ Civil Engineering Department ${ }^{2}$ \\ Postgraduate of Vocational \& Technology Education ${ }^{3}$ \\ Librarian of Home Economics Department ${ }^{4}$ \\ Universitas Negeri Surabaya \\ Surabaya, Indonesia \\ luthfiyahnurlaela@unesa.ac.id
}

\begin{abstract}
Based on the observation in the vocational high school, the students' creative thinking skill was still low. This is because there is no collaboration between learners and teachers to solve problems. Also, there is lack of opportunities given to learners to find their own knowledge. This study developed the inquiry-based learning tools to enhance students' creative thinking skills in vocational high schools. The purpose of this study was to: 1) describe whether validation of learning devices declared from the expert worthy of use in learning; 2) analyze the implementation of learning tools on the inquirybased learning process; 3 ) analyze the activities of learners during the learning activities; 4) analyze the learning outcomes of creative thinking skill obtained by learners before and after implementing inquiry-based learning; and 5) analyze learners' responses to the learning activities. Learning tools developed in this study include syllabus, lesson plan, student activity sheet, and test of creative thinking skill. Data collection was done by test, observation, and questionnaire. Data analysis was done by descriptive analysis and t-test. The results showed that: 1) validation of learning tools from experts declared appropriate for use in learning; 2) the implementation of lesson plan obtained the criteria performed very well, appropriately, systematically, and on time; 3 ) the activities of the learners during the learning activities were in accordance with the inquiry-based learning stages; 4) there was a significant difference to the improvement of creative thinking learning result test obtained by learners before and after inquiry based learning; and 5) the learners' responses to inquiry-based learning activities were in good categories.
\end{abstract}

Keywords-Inquiry Based Learning, Creative Thinking Skills, Vocational High School.

\section{INTRODUCTION}

According to Filsaime, creative thinking is a process of thinking that has the characteristics of fluency, flexibility, originality. Starko and Fisher also add another creative thinking component that is elaboration or add ideas to make it more clear [1]. Creative thinking is defined as a mental activity that a person uses to develop new ideas fluently and felxibilty [2]. In line with the idea it is basically known that students learn according to their learning style, and each learning style influences the thinking process and learning outcomes [3]. The following opinion reinforces the above notion that the component of creative thinking consists of fluency, flexibility, and novelty [4]. From some opinions above it can be concluded that creative thinking is the ability of learners to connect ideas into new ideas that have indicators fluency, flexibility, and novelty.

Thinking skills are defined as the type of ability to view events, conditions or thoughts with careful views in making comments, decisions, checks on the reliability and validity of such knowledge in accordance with logical standards and thinking [5]. Meanwhile, this high-level thinking ability provides an opportunity to deal with existing knowledge and situations in order to correct errors and lack of equipment to achieve a suitable situation [6].

High-level thinking skills and thinking skills affect the success of the learning process. In enhancing high-order thinking skills requires wise consideration in instructional techniques and commitment to an active environment centered on learners [7]. This is consistent with the suggestion that high-level thinking can only be developed if learners are given the opportunity to actively synthesize information in such a way as to complement and extend existing understanding [8]

Innovative learning is defined as learning that enables learners to build experience and skills in their own way, emphasizes on the process and not just on the results and develops students' thinking and creativity skills. Various innovative learning models include instruction-based, problem-based, project-based, collaborative, cooperative learning models with various approaches, such as scientific and contextual approaches. It is also possible to apply various learning strategies. With the implementation of innovative learning model, it is expected that there will be improvement on the quality of process and learning outcomes of learners in Vocational School, such as increasing the activity of learners, the response to the increased learning, critical thinking skills, creative, and problem solving.

Inquiry based-learning is perfect for creative thinking skills and innovative. John Dewey suggests that learning 
development and growth of a human will be optimal when they are faced with real and substantive problems to solve. John Dewey believes that curricula and instruction should be based on integrative community-based tasks and activities and engage learners in pragmatic social actions that bring real benefits to the world. Inquiry begins in a state of uncertainty and leads to the need to overcome uncertainty and restore balance [9].

Inquiry assumes that schools do their best to facilitate self-development. While the teacher in the model of inquiry based learning acts as a facilitator who challenges the learners by helping students to identify questions and problems, and guide the inquiry to be done.

The inquiry learning model has seven learning steps or syntax, namely: 1) formulating problem to be solved by learners; 2) establishing a temporary answer or better known as the hypothesis; 3 ) seeking information, data retrieval, and facts needed to answer the hypothesis or problem; 4) conducting experiments; 5) attempting to find meaning from data collected to answer research questions; 6) presenting the results of the inquiry to peers and teachers and providing feedback by way of discussion; and 7) reflecting from the results of the discussion and evaluating the results of the investigation [10].

The process of finding something new for learners was in formulating hypotheses and testing by experimenting [11]. The idea of inquiry-based learning is an educational strategy whereby learners follow methods and practices by experimenting to build their knowledge [12]. Whereas according to another opinion that learners in doing the learning process independently should conduct experiments to investigate the relationship between one independent variable and one dependent variable [13]. The following statement reinforces the above opinion that inquiry-based learning emphasizes the active participation and responsibility of learners and encourages discovering new knowledge for learners [14].

Based on some of the opinions of the experts above, it can be concluded that inquiry means a series of learning activities that involve maximally all the ability of learners to seek and investigate systematically, logically, analytically and critically. Learners can formulate their own invention fully in learning activities; develop students' confident attitudes about what is found in the inquiry process.

\section{METHOD}

This research took place in SMK KAL-1 Surabaya, because this school is one of the referral schools in Surabaya that has adequate facilities so that it is suitable for the research purpose to develop creative thinking skill based on learners' inquiry. The subjects of this study are 40 students of class $\mathrm{X}$ of Technical Audio Video Expertise Competences, with Ohm's Law material.

The data collection tecniques used in this study were test, observation, and questionnaire. Research instruments include observation sheet for lesson plan implementation, learners' activity, and questionnaire for response of learners. Learning tools developed include syllabus, learning implementation plan, student activity sheet and learning results test of creative thinking.

Data analysis technique in this research include descriptive and inferential statistic. Descriptive statistics was used to explain the results of implementation of lesson plan, student activities, and student responses [15]. Inferential statistics in this study was paired t test to compare student learning outcomes before (pre-test) and after learning (posttest)[16]. Data analysis technique in this test was done with the help of SPSS version 20.

\section{RESUlT AND Discussion}

Based on the data, the following were obtained, i.e. the learning tools validation sheet, the observation sheet of the learning process, the observation sheet of learners' activity, the test of learning outcomes of creative thinking, the questionnaire of the learners' response to the learning activities. Then, the results reveal the following points.

Prior to testing, learning tools and research instruments were validated by two experts using validation and questionnaire sheets. Validated learning tools include syllabus, lesson plan (RPP), student worksheet (LKS), and learning result test of creative thinking. Validated research instruments included observation sheets of RPP implementation, student activity questionnaires, and student response questionnaires. The results of learning tools validation were as follows: syllabus 3.42, RPP 3.38, LKS 3,57 , learning result test of creative thinking 3.7 , observation sheet of implementation of RPP 3.28, questionnaire of learners activity 3.33, and questionnaire response learners 3.3. Overall, the results of validation of learning tools and research instruments had an average value of 3.43. This value indicated that learning tools and research instruments can be used in very good category.

Observation of the implementation of RPP was conducted by two observers by using the observation sheet of the implementation of RPP. Observed aspects include preliminary activities, core activities, and closing activities, in accordance with the inquiry-based learning syntax. The results of the assessment of two observers on the implementation of an inquiry-based RPP at the first and second meetings had an average score of 3.78. This value indicates that the teacher who performed the RPP was in accordance with the syntax of the inquiry learning model well. This is very possible, because before implementing the lesson, the teacher did simulation first. The success of a learning activity is determined by the quality of RPP because RPP contains steps of learning process conducted by teachers and learners.

Observation sheets were used to observe student activities in learning activities. They were made by two observers. Observed activities included listening to or paying attention to the teacher's explanations, reading guidebooks, observing instructional media presentations, engaging in group discussions, watching other group presentations, raising opinions, responding, and irrelevant activities. Based on the observations, it revealed that the activities of learners were in accordance with the stages of inquiry-based learning. Highest student activity was on students' activity in group discussion, amounting to $39 \%$. Although there was irrelevant activity that was $2.75 \%$, the percentage was small and this was reasonable in a lesson. Learning activities in inquiry based learning was an effective and attractive strategy for students. Students seek answers to the questions in solving the problem [17] [18]. Students feel challenged and thus can increase their activity in learning. 
Based on the result of t-paired test, the value of probability (sig. 2-tailed) is 0.000 , which was smaller than $5 \%$ significant level (sig .0.05). Thus it can be said that there was an increase in learning outcomes obtained by students before and after the learning activities based on inquirybased learning. Inquiry-based learning is defined as a learning strategy based on knowledge discovery that directs students to participate actively and responsibly in the learning process [19] [20]. In line with the idea, inquirybased learning is a learning approach whereby learners are directed to solve problems using inquiry skills from learners [21]. Inquiry learning is highly recommended as a fun learning to encourage curiosity and motivate students in learning inquiry at school.

Questionnaire response to learning activities is given to students after the learning. Student responses are intended to elicit their responses to aspects of component novelty, which include materials/content, instructional media, test of learning outcomes, student worksheets, learning atmosphere, and teacher method of teaching. The results of the questionnaire of the learners' responses to the learning activities can be seen in Table I below.

TABLE I. QUESTIONNAIRE' ON STUDENT'S RESPONSES TO LEARNING ACTIVITIES

\begin{tabular}{|c|c|c|c|}
\hline No & Aspect & Category & $\begin{array}{l}\text { Percentage } \\
\text { Value }\end{array}$ \\
\hline \multirow[t]{3}{*}{1} & \multirow[t]{3}{*}{ Novelty } & New & $83.33 \%$ \\
\hline & & Simply New & $16.25 \%$ \\
\hline & & Not New & $0.42 \%$ \\
\hline \multirow[t]{3}{*}{2} & \multirow{3}{*}{$\begin{array}{l}\text { Ease of understanding } \\
\text { language and question } \\
\text { of evaluation }\end{array}$} & Easy & $76 \%$ \\
\hline & & Quite easy & $23 \%$ \\
\hline & & Not easy & $1 \%$ \\
\hline \multirow[t]{2}{*}{3} & \multirow[t]{2}{*}{ Interest } & Interested & $85 \%$ \\
\hline & & Quite interested & $15 \%$ \\
\hline \multirow[t]{2}{*}{4} & \multirow[t]{2}{*}{ Way of teaching } & Clear & $78.75 \%$ \\
\hline & & Quite clear & $21.25 \%$ \\
\hline
\end{tabular}

The results of the analysis obtained that as many as $83.33 \%$ learners declare the learning tools used was new. Viewed from the aspect of ease in understanding the language and the question of evaluation, as much as $76 \%$ of the learners consider it easy. Based on the aspect of interest, as many as $85 \%$ of learners were interested in. Judging from the way teachers teach, as many as $78.75 \%$ of learners feel the way of teaching was clear.

Based on these data, it appears that learners pay attention to the application of inquiry learning model and appreciate all components of learning with a good response. The content of inquiry-based learning focused on student ideas and relevant to the interests of learners as well as balanced with the experience of everyday learners [22] [23]. In addition, students play a role in exploring information as a basis for planning inquiry and learners can use the ability to ask and think, and learn new ideas and concepts [24] [25] [26].

\section{CONCLUSION}

Based on the results of data analysis, the following conclusions are drawn: 1) learning tools were declared eligible to use; 2) there was an increase in learning outcomes of creative thinking obtained by students before and after inquiry based learning; 3) RPP obtains the criteria performed very well, according to the syntax of inquiry learning, runs systematically, and on time; 4) the activities of learners during the learning activities were in accordance with the stages of inquiry-based learning; and 5) the learners' response to the inquiry-based learning activities was good.

\section{REFERENCES}

[1] Filsaime, D. K. Menguak rahasia berpikir kritis dan kreatif. Jakarta: Prestasi Pustaka, 2008, pp 80-81

[2] Nurlaela, L. \& Euis I. Strategi belajar berpikir kreatif. Yogyakarta: Ombak, 2015, pp. 2

[3] Nurlaela, Lutfiyah. Model pembelajaran, gaya belajar, kemampuan membaca dan hasil belajar. Surabaya: University Press, 2011, pp 20 22

[4] Suparji. Creative thinking level of student in measuring situation map area through multiple solution tasks (case study on nganjuk state-1 vocational high school). Journal of Basic and Applied Scientific Research. vol 7. ISSN 2090-4304, 2017, pp. 28-33

[5] Seferoglu, S. S. \& Akbıyık, C. Teaching critical thinking. Hacettepe University Journal of Education, vol 30, 2006, pp. 193-200

[6] Howard, L. W., Tang, T., \& Austin, M. J. Teaching critical thinking skills: Ability, motivation, intervention, and the Pygmalion effect. Journal of Business Ethics, vol 128, 2015, pp. 133-147

[7] Limbach, B \& Waugh. W. Developing higher level thinking. Journal of Instructional Pedagogies: Chadron State College, 2009, pp. 9

[8] Knapp, L. Roehrig \& Glenn, A. D. Restructuring school with technology. Massachusettes: Ally \& Bacon, 1996, pp 158

[9] Lee. V. S. “The power of inquiry as a way of learning”. Innovative Higher Education 36, vol 3, 2011, pp. 149-160

[10] Scanlon, E., Anastopoulou, S., Kerawalla, L., \& Mulholland, P. How technology resources can be used to represent personal inquiry and support students' understanding of it across contexts. Journal of Computer Assisted Learning, vol 27, doi:10.1111/j.13652729.2011.00414, 2011, pp. 516-529

[11] Pedaste, M., Mäeots, M., Leijen, Ä., \& Sarapuu, S. Improving students' inquiry skill through reflection and self-regulation scaffolds. Technology, Instruction, Cognition and Learning, vol 9, 2012, pp. $81-95$

[12] Keselman, A. Supporting inquiry learning by promoting normative understanding of multivariable causality. Journal of Research in Science Teaching, vol 40.doi: 10.1002/tea.10115, 2003, pp. 898-921

[13] Wilhelm, P., \& Beishuizen, J.J. Content effects in self-directed inductive learning. Learning and Instruction, vol 13. doi: 10.1016/S0959-4752(02)00013-0, 2003, pp. 381-402

[14] De Jong, T., \& Van Joolingen, W. R. Scientific discovery learning with computer simulations of conceptual domains.Review of Educational Research, vol 68. doi: 10.2307/1170753, 1998, pp. 179202

[15] Sugiyono. Metode penelitian kuantitatif kualitatif dan $R \& D$. Bandung: Alfabeta, 2014, pp 43

[16] Sugiyono.Memahami penelitian kualitatif. Bandung: Alfabeta, 2012, pp 1

[17] Munandar.Pengembangan kreativitas anak berbakat. Jakarta: Rineka Cipta, 2009, pp 145

[18] Kim, K.H. The creativity crisis: the decrease in creative thinking scores on the torrance test of creative thinking. Creativity Research Journal, 23 vol 4. DOI: 10.1080/10400419.2011.627805, 2011, pp. 285-295.

[19] Piaget, J. The language and thought of the child, vol 5. London: Phsychology Press, 1959, pp 104

[20] Iru, La \& La Ode Safiun Arihi. Analisis penerapan pendekatan, metode, strategi, dan model-model pembelajaran. Yogyakarta: Multi Presindo. 2012, pp. 8-9

[21] Pedaste, M., \& Sarapuu. Developing an effective support system for inquiry learning in a web-based environment. Journal of computer assisted learning, vol 22, 2006, pp. 47-62

[22] Johnson L. \& Leny R. Keperawatan keluarga: plus contoh askep keluarga. Cetakan I. Yogyakarta: Nuha Medika, 2010, pp 88

[23] Nurlaela, L. \& IGP Asto Buditjahjanto. Implementasi teknologi informasi dan komunikasi dalam pembelajaran bidang vokasi. Jurnal Teknologi Pendidikan, Teori dan Praktik.vol 2, 2013, no 2 
[24] Kurniasih \&Sani.Model pembelajaran. Yogyakarta: Kata Pena, 2015, pp 28

[25] A.M. Sardiman. Interaksi dan motivasi belajar mengajar. Jakarta: PT Raja Grafindo Persada, 2010, pp 156-157

[26] Hamalik, O. Kurikulum dan pembelajaran. Jakarta: Bumi Aksara. 2011, pp 57-58 